\title{
Fusarium oxysporum f. sp. palmarum, a Novel Forma Specialis Causing a Lethal Disease of Syagrus romanzoffiana and Washingtonia robusta in Florida
}

\author{
M. L. Elliott and E. A. Des Jardin, Fort Lauderdale Research and Education Center, University of Florida-IFAS, \\ Davie 33314; K. O’Donnell, Microbial Genomics Research Unit, Agricultural Research Service, United States De- \\ partment of Agriculture, Peoria, IL 61604; D. M. Geiser, Department of Plant Pathology, The Pennsylvania State \\ University, University Park 16802; and N. A. Harrison and T. K. Broschat, Fort Lauderdale Research and Educa- \\ tion Center, University of Florida-IFAS, Davie
}

\begin{abstract}
Elliott, M. L., Des Jardin, E. A., O’Donnell, K., Geiser, D. M., Harrison, N. A., and Broschat, T. K. 2010. Fusarium oxysporum f. sp. palmarum, a novel forma specialis causing a lethal disease of Syagrus romanzoffiana and Washingtonia robusta in Florida. Plant Dis. 94:31-38.

A new disease of Syagrus romanzoffiana (queen palm) and Washingtonia robusta (Mexican fan palm) has spread across the southern half of Florida during the past 5 years. The initial foliar symptom is a one-sided chlorosis or necrosis of older leaf blades, with a distinct reddish-brown stripe along the petiole and rachis and an associated discoloration of internal tissue. Within 2 to 3 months after onset of symptoms, the entire canopy becomes desiccated and necrotic but the leaves do not droop or hang down around the trunk. Based on pathogenicity and morphological and molecular characterization, the etiological agent has been identified as a new forma specialis of Fusarium oxysporum, designated f. sp. palmarum. Sequence analysis of a portion of the translation elongation factor 1- $\alpha$ gene $(E F-1 \alpha)$ separated 27 representative isolates into two $E F-1 \alpha$ groups, which differed by two transition mutations. Members of both $E F-1 \alpha$ groups are pathogenic on both species of palm. A phylogenetic analysis inferred from partial $E F-1 \alpha$ sequences from a genetically diverse set of $F$. oxysporum isolates, including three other formae speciales pathogenic on palm (i.e., f. sp. albedinis, f. sp. canariensis, and f. sp. elaeidis), suggested that $\mathrm{f}$. sp. palmarum and f. sp. albedinis may be more closely related to one another than either is to the two other palm pathogens.
\end{abstract}

Syagrus romanzoffiana (Cham.) Glassman (queen palm) and Washingtonia robusta H.A. Wendl. (Mexican fan palm) are widely used ornamental palm trees grown in Florida landscapes. Neither palm species is native to Florida but both became popular after the lethal yellowing epidemic in the 1970s killed large numbers of Cocos nucifera (coconut palm) in southeastern Florida, because they are not susceptible to this phytoplasma disease (13). Also, because they are relatively cold tolerant, they can be grown as far north as interior central Florida and along the entire Atlantic coast of the state. Nutritional deficiencies

Corresponding author: M. L. Elliott

E-mail: melliott@ufl.edu

The mention of firm names or trade products does not imply that they are endorsed or recommended by the United States Department of Agriculture over other firms or similar products not mentioned.

GenBank accession numbers: GQ154454, GQ154455, GQ154456, GQ154457, GQ154458, GQ154459, GQ154460, GQ154461, GQ154462, GQ154463, GQ154464, GQ154465, GQ154466, GQ154467, GQ154468, GQ154469.

Accepted for publication 7 August 2009.

doi:10.1094/PDIS-94-1-0031

(C) 2010 The American Phytopathological Society are a common cause of decline of both species, although this type of slow decline can be corrected by appropriate fertilization. Until recently, the primary lethal diseases observed on these two palm species were Ganoderma butt rot, caused by Ganoderma zonatum, and Thielaviopsis trunk rot, caused by Thielaviopsis paradoxa (5).

Mature queen palm trees that died quickly in 2 to 3 months were first brought to our attention in late 2004, with new landscape sites continuously reported throughout the southern half of the state since that time. In spring 2007, Mexican fan palm trees with similar symptoms and disease progression were also observed at several locations throughout the southern half of the state and continue to be reported. Affected palm trees have been observed mostly in mature landscapes; however, juvenile palm trees with symptoms were also found in a container nursery and in two field nurseries.

Early-stage foliar symptoms on both queen and Mexican fan palm resemble those associated with Fusarium wilt of Phoenix canariensis (Canary Island date palm), a disease which is well established in Florida and is caused by Fusarium oxysporum f. sp. canariensis (19). Initial symptoms on individual leaves of affected palm trees appear as a chlorosis and necro- sis on one side of the leaf blade (one-sided wilt or death) together with a distinct reddish-brown stripe along the petiole and rachis and an associated discoloration of internal tissues (vascular and parenchyma). The entire leaf quickly becomes necrotic. These symptoms develop first on the oldest leaves and then progress to successively younger leaves in the canopy. There is no evidence of trunk infection. Within 2 to 3 months after the onset of leaf symptoms, the entire canopy becomes desiccated and necrotic but the leaves do not droop or hang down around the trunk (i.e., the canopy is necrotic but does not collapse; Fig. 1). At this terminal stage of disease development, the apical meristem becomes infected and dies, and the pathogen invades the trunk tissue. Because the disease kills so quickly, there is no obvious reduction in leaf number or canopy size.

The objectives of this study were to isolate and characterize, both morphologically and molecularly, potential pathogens from symptomatic palm tissues and conduct pathogenicity tests to determine the etiological agent of this new disease.

\section{MATERIALS AND METHODS}

Pathogen isolation. Leaves from symptomatic palm trees were collected from sites throughout the southern half of Florida (Table 1). Samples (approximately 2 by $2 \mathrm{~mm}$ ) of discolored internal petiole or rachis tissue, including vascular and parenchyma tissue were obtained from these symptomatic leaves. Tissues were placed onto one-fifth strength Difco potato dextrose agar (1/5 PDA) and 1/5 PDA amended with streptomycin sulfate at 100 $\mu \mathrm{g} \mathrm{ml}^{-1}$. Initially, half of the samples were incubated in the dark and the remaining samples were incubated with $12 \mathrm{~h}$ of light each day. Lighting consisted of one $20-\mathrm{W}$ Verilux full-spectrum bulb and one 20-W Philips Cool White bulb. As it became increasingly evident that one or more Fusarium spp. might be the etiological agent, samples were incubated exclusively with $12 \mathrm{~h}$ of light. Additionally, symptomatic petiole or rachis pieces (approximately $5 \mathrm{~cm}$ in length), thoroughly washed and then surface sterilized with ethanol, were placed in a moisture chamber to encourage fungal growth and sporulation. 
Pathogen characterization. Fusariumlike colonies were consistently isolated from symptomatic tissue, both on 1/5 PDA and directly from petiole or rachis tissue. Single conidial cultures were established on 1/5 PDA, and resulting isolates were stored as colonized agar plugs in sterile deionized water in cryogenic vials at room temperature or on 1/5 PDA slants at $28^{\circ} \mathrm{C}$. Single-conidial isolates were characterized morphologically by growing them on PDA and $1.5 \%$ water agar with $\gamma$-irradiated carnation leaves embedded in the agar surface (CLA) for 2 to 4 weeks at $26^{\circ} \mathrm{C}$ with $12 \mathrm{~h}$ of light, using the light sources described previously. Cultures were examined for the presence and characteristics of microconidia, mesoconidia, macroconidia, chlamydospores, sclerotia, coloration of medium, and colony morphology (15).

For molecular characterization, all Fusarium isolates were grown in 2 to $5 \mathrm{ml}$ potato dextrose broth at $28^{\circ} \mathrm{C}$ in darkness for 3 to 4 days without shaking. DNA was extracted from the mycelial cultures using a Gentra PureGene cell kit (Qiagen, Inc.,
Valencia, CA.). DNA was then used for polymerase chain reaction (PCR) using the ef 1 and ef 2 primers $\left(53^{\circ} \mathrm{C}\right.$ annealing temperature, 34 cycles) to amplify a portion of the translation elongation factor $1-\alpha$ gene $(E F-1 \alpha)$, a highly informative region for differentiating Fusarium spp. and many formae speciales within the $F$. oxysporum species complex, as previously described (11). Aliquots $(10 \mu \mathrm{l})$ of PCR products were evaluated by electrophoresis through a 1\% agarose gel using Tris-acetate EDTA (40 mM Tris-acetate, $1 \mathrm{mM}$ EDTA) as running buffer. PCR products were purified on spin columns (Wizard PCR Preps DNA Purification System; Promega Corp., Madison, WI) and sequenced directly with primers ef1 and ef2. Sequencing was performed at the University of Florida's Core Sequencing Service Laboratory.

Sequences were edited and then queried for similarity against the FUSARIUM-ID database using the BLAST search tool (http://fusarium.cbio.psu.edu; 11). This database, unlike GenBank, contains sequences of vouchered and well-characterized

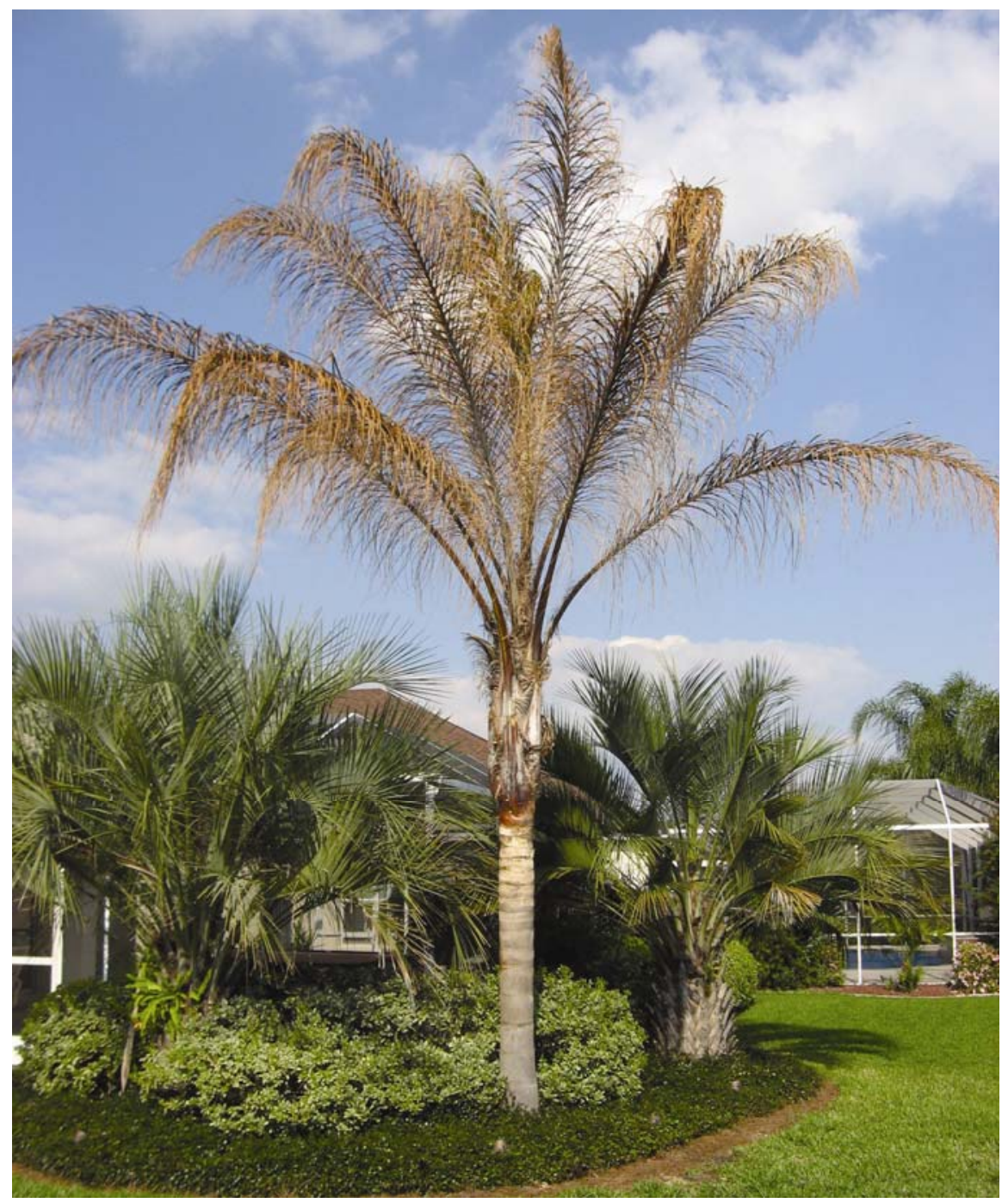

Fig. 1. Syagrus romanzoffiana (queen palm) exhibiting typical late-stage symptoms of Fusarium wilt caused by Fusarium oxysporum f. sp. palmarum. Canopy is necrotic but leaves do not droop or hang down around the trunk. Photo used with permission of Brooke Burn. strains of Fusarium. F. oxysporum sequences were then aligned using CLUSTAL W (23) with the following parameters: gap opening penalty of 5.0, gap extension penalty of 0.2 , DNA transition weight of 0.5 , delay divergent cutoff of $30 \%$. A phylogenetic distance tree was constructed from the alignment by the neighbor-joining method using MEGA 3.1 software (14). The partial $E F-1 \alpha$ sequence of $F$. oxysporum f. sp. canariensis NRRL 26035 was used as the outgroup to root the tree.

Sequencher version 4.1.2 (Gene Codes, Ann Arbor, MI) was used to edit and align the partial $E F-1 \alpha$ sequences of seven Florida palm pathogen isolates of $F$. oxysporum, including the four used for the pathogenicity experiments described below. Next, $E F-1 \alpha$ sequences of 22 phylogenetically diverse members of the $F$. oxysporum species complex (FOSC), including representatives of the palm pathogens f. spp. canariensis, elaeidis, and albedinis, were added to the Florida palm pathogen dataset to assess their phylogenetic relationships. Maximum parsimony analysis of the $E F-1 \alpha$ dataset was conducted in PAUP* (21), using two sequences of the sister taxon of the FOSC, $F$. foetens, to root the phylogeny. Clade support was assessed by nonparametric bootstrapping, employing 10 random addition sequences per replicate, TBR branch swapping, and 1,000 pseudoreplicates of the data. Based on analysis of the $E F-1 \alpha$ dataset, partial $E F-1 \alpha$ (635-bp alignment) sequences and nearly complete nuclear ribosomal intergenic spacer (IGS) ribosomal (r)DNA (2,220-bp alignment) sequences were used to determine two-locus haplotypes for 10 of the Florida palm pathogens (including the 4 used for the pathogenicity experiments), employing a comprehensive dataset for members of the FOSC (16).

Pathogenicity experiments. For all pathogenicity experiments, Fusarium isolates were grown on PDA at $26^{\circ} \mathrm{C}$ with 12 $\mathrm{h}$ of light per day for at least 2 weeks, using the light sources described previously. Conidial suspensions were prepared by first adding sterile water to each PDA culture, dislodging spores from the mycelia using a sterile bent glass rod, and then filtering the resulting suspension through two layers of sterile cheesecloth. The inoculum consisted of a $10^{7}$ conidia $\mathrm{ml}^{-1}$ suspension.

Experiment 1. F. oxysporum isolates PLM-140B and PLM-153B were used as inoculum in the first pathogenicity experiment. Both isolates were obtained early in the study from mature diseased queen palm trees growing in landscapes. The experiment was begun during April 2006 and used young queen palm trees (four to five true leaves, no trunk) grown in approximately 10 -liter containers. Palm trees were inoculated separately with the iso- 
lates by one of two methods. Palm trees were inoculated by drilling a 4-mmdiameter hole into the stem apex 8 to 10 $\mathrm{cm}$ above the soil line, followed by gradually injecting $2 \mathrm{ml}$ of spore suspension into the hole with a sterile 18-gauge syringe (9). Alternatively, palm trees were inoculated by cutting a shallow slit, $5 \mathrm{~cm}$ in length, into the adaxial surface of the petiole on the second youngest fully expanded leaf, and slowly applying $1 \mathrm{ml}$ of spore suspension into the wound. Palm trees designated as negative controls were treated in the same manner using sterile water only. Four replicate palm trees were used for each treatment. All treated palm trees were immediately covered with clear, polyethylene bags and placed in an area without direct sun for 3 days to prevent excessive heat in the bags. The bags were then removed, and the palm trees were maintained in a full-sun nursery with daily overhead irrigation. Palm trees were transplanted into approximately 24-liter containers after 2 months. Once palm trees expressed foliar disease symptoms, affected leaves were removed and pathogen isolations were attempted as previously described. The identity of $F$. oxysporumlike isolates was confirmed by a PCR assay employing the ef 1 and ef 2 primers and sequencing of $E F-1 \alpha$ gene amplicons as described above. Sequences were com- pared with those obtained from the isolates used as inoculum. The experiment was terminated after 9 months.

Experiment 2. Isolates of $F$. oxysporum (PLM-140B), F. proliferatum (PLM137B), and $F$. incarnatum-equiseti species complex (hereafter referred to as FIESC) (PLM-138B) were used for the second pathogenicity experiment. All three isolates were obtained from the same diseased queen palm. Containerized (2.5-liter) juvenile queen palm trees were used for this experiment. The palm trees possessed three to four leaves (one to two seedling leaves and two to three juvenile leaves). Palm trees were inoculated separately with each of the three Fusarium spp. by one of two methods. The first method was essentially the same as the injection protocol previously described in experiment 1. A 3mm-diameter hole was drilled into the stem apex 4 to $5 \mathrm{~cm}$ above the soil line, and a 2-ml spore suspension was gradually injected into the hole with a sterile 18gauge syringe. For the second method, a 50-ml spore suspension was carefully poured around the base of each palm and over the potting mix (pour-on method). Palm trees designated as negative controls were treated in the same manner but were inoculated with sterile water only. In total, there were eight treatments: three different isolates and a water control applied to palm trees by two methods. Palm trees were covered in clear, polyethylene bags and placed in an area without direct sun for 3 days. The bags were then removed, and the palm trees were placed in a structure with shade-cloth walls and a clear polycarbonate sheet roof. The palm trees received daily overhead irrigation. The experiment was terminated after 9 months.

Experiment 3. $F$. oxysporum isolates PLM-140B (recovered from a queen palm in a landscape), PLM-246B (from a queen palm in a field nursery), and PLM-249A (from a Mexican fan palm in the same field nursery as PLM-246B) were selected for the third pathogenicity experiment, begun in May 2007, using queen and Mexican fan palm seedlings (three to four seedling leaves) as hosts. Palm trees in tree cones were inoculated by pipetting a $40-\mathrm{ml}$ spore suspension between the leaf bases, allowing excess suspension to percolate into the potting mix. Palm trees designated as negative controls were treated in the same manner but with sterile water only. Once inoculated, the palm trees were covered with clear, polyethylene bags and placed in an area without direct sun for 3 days. The bags were then removed, and the palm trees were transplanted into $450-\mathrm{ml}$ containers using a pine bark/sedge peat/ sand $(1: 1: 1)$ potting mix. Palm trees were then placed in a structure with shade-cloth

Table 1. Isolates of Fusarium oxysporum f. sp. palmarum isolated in Florida from diseased Syagrus romanzoffiana (queen palm), S. romanzoffiana $\times$ Butia capitata, and Washingtonia robusta (Mexican fan palm)

\begin{tabular}{|c|c|c|c|c|c|c|c|}
\hline Florida isolate no. & $\begin{array}{c}\text { NRRL } \\
\text { no. }^{\mathrm{a}}\end{array}$ & County & Geographic location & Location type & $\begin{array}{c}\text { Date sample } \\
\text { collected }\end{array}$ & $\begin{array}{l}\text { Two-locus } \\
\text { haplotype }^{\text {b }}\end{array}$ & $\begin{array}{l}\text { GenBank } \\
\text { acc. no.c }\end{array}$ \\
\hline \multicolumn{8}{|l|}{ S. romanzoffiana } \\
\hline PLM-43D & & Palm Beach & West Palm Beach & Landscape & March 2005 & $\ldots$ & \\
\hline PLM-119C & 46584 & Martin & Stuart & Container nursery & June 2005 & s & GQ154464 \\
\hline PLM-140B & 46585 & Broward & Davie & Landscape & September 2005 & ST 250 & GQ154454 \\
\hline PLM-153B & 53544 & Manatee & Lakewood Ranch, WM7043 & Landscape & December 2005 & ST 251 & GQ154455 \\
\hline PLM-155D & & Manatee & Lakewood Ranch, WM7049 & Landscape & December 2005 & $\ldots$ & \\
\hline PLM-160C & 46586 & Manatee & Lakewood Ranch, WM7088 & Landscape & December 2005 & $\ldots$ & GQ154465 \\
\hline PLM-179D & 46587 & Manatee & Lakewood Ranch, WM7032 & Landscape & May 2006 & $\ldots$ & GQ154466 \\
\hline PLM-181C & 46588 & Martin & Stuart & Landscape & June 2006 & & GQ154467 \\
\hline PLM-192D & 46589 & Orange & Orlando, Coronado & Landscape & June 2006 & ST 251 & GQ154456 \\
\hline PLM-199B & 46590 & Manatee & Lakewood Ranch, SG & Landscape & August 2006 & ST 251 & GQ154457 \\
\hline PLM-231 & & Manatee & Lakewood Ranch, EW & Landscape & January 2007 & & - $2=$ \\
\hline PLM-246B & 53541 & Lee & North Fort Myers & Field nursery & April 2007 & ST 251 & GQ154458 \\
\hline PLM-269A & 46594 & Lee & North Fort Myers & Field nursery & June 2007 & ST 251 & GQ154459 \\
\hline PLM-278 & $\ldots$ & Orange & Orlando, Coronado & Landscape & May 2007 & $\ldots$ & $\ldots$ \\
\hline PLM-344 & $\ldots$ & Indian River & Fort Pierce & Field nursery & November 2007 & $\ldots$ & $\ldots$ \\
\hline PLM-351 & $\ldots$ & Indian River & Vero Beach, barrier island & Landscape & December 2007 & $\ldots$ & $\ldots$ \\
\hline PLM-369 & $\ldots$ & Indian River & Vero Beach, mainland & Landscape & February 2008 & $\ldots$ & $\ldots$ \\
\hline PLM-388 & $\ldots$ & Sarasota & Sarasota & Landscape & June 2008 & $\ldots$ & $\ldots$ \\
\hline \multicolumn{8}{|c|}{ S. romanzoffiana $\times$ B. capitata } \\
\hline PLM-320B & 53542 & Pinellas & St. Petersburg & Landscape & August 2007 & ST 284 & GQ154460 \\
\hline PLM-321E & 53540 & Pinellas & St. Petersburg & Landscape & August 2007 & ST 284 & GQ154461 \\
\hline \multicolumn{8}{|l|}{ W. robusta } \\
\hline PLM-249A & 53543 & Lee & North Fort Myers & Field nursery & April 2007 & ST 251 & GQ154462 \\
\hline PLM-256D & 46591 & Pinellas & St. Petersburg & Landscape & June 2007 & ST 251 & GQ154463 \\
\hline PLM-258B & 46592 & Orange & Orlando, All Star Music & Landscape & June 2007 & $\ldots$ & GQ154468 \\
\hline PLM-265D & 46593 & Lee & North Fort Myers & Field nursery & June 2007 & $\ldots$ & GQ154469 \\
\hline PLM-336D & $\ldots$ & St. Lucie & Port St. Lucie & Landscape & September 2007 & $\ldots$ & $\ldots$ \\
\hline PLM-338D & $\ldots$ & Orange & Orlando, All Star Music & Landscape & October 2007 & $\ldots$ & $\ldots$ \\
\hline PLM-382 & $\ldots$ & Orange & Orlando, Hollywood Studios & Landscape & April 2008 & $\ldots$ & $\ldots$ \\
\hline
\end{tabular}

a Agricultural Research Service Culture Collection (NRRL), National Center for Agricultural Utilization Research, Peoria, IL (http://nrrl.ncaur.usda.gov).

${ }^{\mathrm{b}}$ Two-locus haplotype (sequence type [ST]) determined by combined analysis of a portion of the translation elongation factor 1- $\alpha$ gene $(E F-1 \alpha)$ and nearly complete nuclear ribosomal intergenic spacer ribosomal DNA region sequences.

${ }^{\mathrm{c}}$ GenBank accession number for portion of $E F-1 \alpha$ gene. 
walls and a clear polycarbonate sheet roof and irrigated daily. Five replicate palm trees were used per treatment and each palm species was inoculated separately with each fungal isolate. This experiment was terminated after 8 months, and repeated again in May 2008.

Experiment 4. In this final experiment, begun in October 2007, the same three isolates of $F$. oxysporum used in experiment 3 (PLM-140B, PLM-246B, and PLM-249A) as well as $F$. proliferatum PLM-137B and FIESC PLM-138B used in experiment 2 were used separately as inoculum. Both queen and Mexican fan palm seedlings (three to four seedling leaves) served as the hosts. Seedlings were subjected to the same inoculation method and subsequent growth conditions as described in experiment 3 . This experiment was terminated after 3 months.

\section{RESULTS}

Pathogen isolation and characterization. Leaf samples were obtained from palm trees exhibiting symptoms of the new disease over a 3-year period from across the southern half of Florida. Many palm trees were located in established (5- to 20year-old) landscape plantings (Table 1). Initially, all samples were collected from declining queen palm trees but, starting in spring 2007, further samples were also obtained from declining Mexican fan palm trees and from a solitary $S$. romanzoffiana $\times$ Butia capitata hybrid palm. The Orange County queen and Mexican fan palm samples were obtained from the same realty development but the sample sites were separated by at least $1 \mathrm{~km}$. Six queen palm samples were obtained from the same city (Lakewood Ranch in Manatee County) but from three separate realty subdivisions. In addition, samples were obtained from one container nursery and two field nurseries in three counties (Table 1). The two field nurseries were on opposite coasts of Florida (Lee County versus Indian River County). The Lee County samples were obtained from a field nursery in which juvenile queen and Mexican fan palm trees were growing in adjacent plots.

Fusarium isolates were consistently recovered from discolored internal tissue of

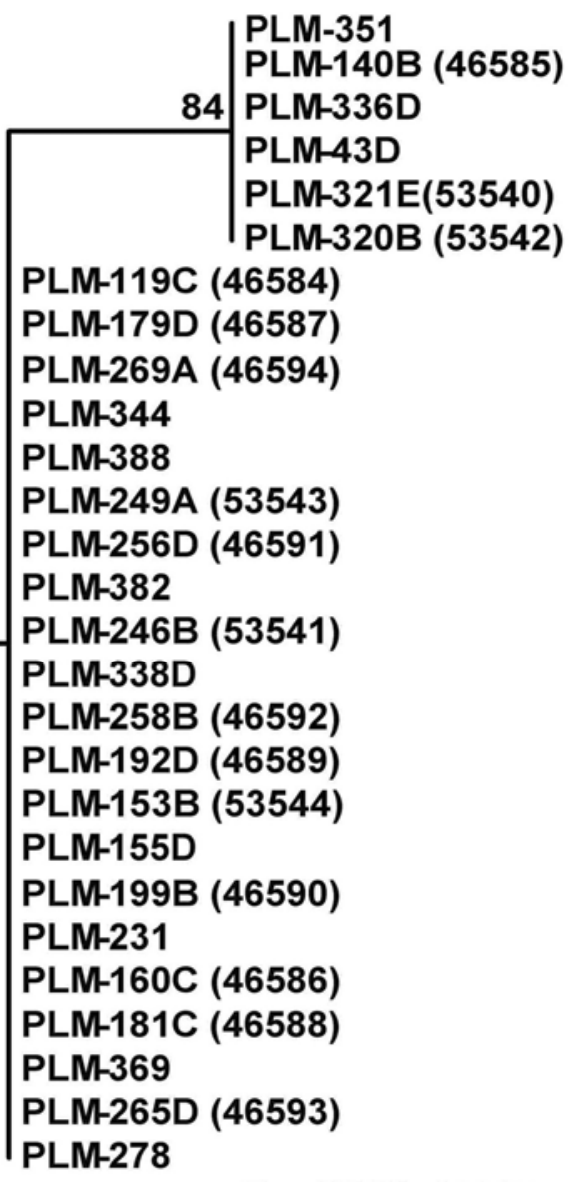

Foc NRRL 26035

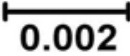

Fig. 2. Phylogenetic tree, constructed by the neighbor-joining method, of partial translation elongation factor 1- $\alpha(E F-1 \alpha)$ gene sequences from representative Fusarium oxysporum f. sp. palmarum isolates listed in Table 1. A sequence of Fusarium oxysporum f. sp. canariensis (Foc NRRL 26035) was used to root the tree. symptomatic petiole and rachis tissue. Fiftyeight isolates from 26 palm trees were examined morphologically and tentatively identified as $F$. oxysporum, $F$. proliferatum, or a member of the FIESC. Although $F$. proliferatum and FIESC were not consistently isolated from symptomatic tissue, as was $F$. oxysporum, at least one of these species was isolated along with $F$. $o x$ ysporum from the same palm on five separate occasions. In one instance in Broward County, all three Fusarium spp. were isolated from the same queen palm tree.

The majority $(n=43)$ of the 58 isolates examined were tentatively identified as $F$. oxysporum. Information on location, host, and sampling date for 27 of these isolates is shown in Table 1. Colonies on PDA were pale pinkish-salmon color on the top surface, except for isolates PLM-43B and PLM-336D, which were purple. Macroconidia were formed in orange sporodochia on CLA. Macroconidia were three to four septate with a foot-shaped basal cell and curved apical cell and ranged from $34.3 \pm$ 3.0 to $47.4 \pm 3.6 \mu \mathrm{m}$ in length and $3.8 \pm$ 0.3 to $5.0 \pm 0.2 \mu \mathrm{m}$ in width (mean of 25 spores/isolate). Microconidia were produced in false heads on short phialides. They were unicellular and were primarily oval, elliptical, or reniform in shape. They ranged in size from $6.8 \pm 0.9$ to $8.6 \pm 1.7$ $\mu \mathrm{m}$ in length and $2.7 \pm 0.4$ to $3.5 \pm 0.7 \mu \mathrm{m}$ in width (mean of 25 spores/isolate). Chlamydospores were readily produced by most isolates in less than 4 weeks. Some isolates produced sclerotia on PDA, which were blue in color.

Colonies produced by isolates of $F$. proliferatum $(n=9)$ on PDA were pale lavender color on the top surface. Macroconidia were longer and more slender than those of F. oxysporum. They were three to four septate with a foot-shaped basal cell and curved apical cell and ranged from $43.3 \pm$ 5.0 to $62.2 \pm 11.3 \mu \mathrm{m}$ in length and $3.3 \pm$ 0.5 to $3.8 \pm 0.3 \mu \mathrm{m}$ in width (mean of 25 spores/isolate). Club-shaped microconidia with a flattened base were present in long chains on polyphialides. They were unicellular and ranged in size from 7.2 $\pm 1.1 \mu \mathrm{m}$ to $8.4 \pm 1.5 \mu \mathrm{m}$ in length and $2.7 \pm 1.5$ to $3.7 \pm 0.7 \mu \mathrm{m}$ in width (mean of 25 spores/isolate). No chlamydospores or sclerotia were produced by any isolate.

Members of the FIESC $(n=6)$ formed colonies on PDA that were salmon-orange color on the top surface. Macroconidia were shorter than those of $F$. oxysporum. They were three to five septate with a rounded basal cell and curved apical cell and ranged from $27.5 \pm 2.1$ to $40.6 \pm 5.7$ $\mu \mathrm{m}$ in length and $3.6 \pm 0.4$ to $6.0 \pm 0.8 \mu \mathrm{m}$ in width (mean of 25 spores/isolate). In addition, mesoconidia were produced instead of microconidia. Fusoid-shaped mesoconidia were present in characteristic pairs on polyphialides. Chlamydospores and sclerotia were not produced by any isolate. 
When partial $E F-1 \alpha$ gene sequences from the 27 representative $F$. oxysporum isolates listed in Table 1 were compared with the $E F-1 \alpha$ sequence of known, vouchered isolates in the FUSARIUM-ID database (11), none matched any of the FOSC formae speciales sequences currently archived in the database, including those for $F$. oxysporum f. sp. canariensis, the etiological agent of Fusarium wilt of Canary Island date palm, which is present in Florida. Phylogenetic analysis resolved the $E F-1 \alpha$ sequences of the 27 Florida $F$. oxysporum isolates into two groups (Fig. 2 ), which differed by two transition mutations. One group included PLM-43D, PLM-140B, PLM-320B, PLM-321E, PLM-351, and PLM-336D, whereas the second group encompassed all remaining isolates listed in Table 1.

Partial EF-1 $\alpha$ (635-bp alignment) sequences and nearly complete IGS rDNA (2,220-bp alignment) sequences were used to determine two-locus haplotypes for 10 of the Florida palm pathogens, employing a comprehensive dataset for members of the FOSC (16). Analysis of these 10 isolates identified three unique two-locus haplotypes, designated sequence types (STs) 250, 251, or 284 (Table 1).

To assess relationships of the Florida palm pathogens to a phylogenetically diverse set of FOSC formae speciales, including isolates pathogenic to Canary Island date palm (f. sp. canariensis), oil palm (f. sp. elaeidis), and date palm (f. sp. albedinis), partial $E F-1 \alpha$ sequences derived from 7 Florida palm isolates (representing the three STs) and 22 other members of the FOSC were analyzed using maximum parsimony (MP). MP analysis of the $E F-1 \alpha$ partition recovered a single most-parsimonious tree (MPT) of 46 steps in which three clades received moderate to strong bootstrap support (Fig. 3). In addition, results of this analysis indicated that the palm pathogens appeared to have independent evolutionary origins in clade 1 (f. sp. canariensis), clade 2 (f. sp. elaeidis), and clade 3 (f. sp. albedinis and f. sp. palmarum). In support of this interpretation, a constraint that forced the monophyly of all four palm formae speciales was four steps longer and significantly worse than the MPT (Kishino-Hasegawa test $P<0.05$ ). By way of contrast, results of the phylogenetic analysis suggest a putatively close phylogenetic relationship of NRRL 26622 f. sp. albedinis (ST 80) and f. sp. palmarum (STs 250, 251, and 284).

Pathogenicity experiment 1. This experiment was initiated prior to obtaining any diseased Mexican fan palm trees; therefore, only juvenile queen palm trees were used as the host. After 9 months, all control palm trees remained healthy but two of four palm trees inoculated with $F$. oxysporum isolate PLM-140B or with PLM-153B, using either method, had died, after first exhibiting leaf symptoms typical of those observed in mature landscape palm trees (i.e., one-sided necrosis with a corresponding reddish-brown stripe). No symptoms developed for at least 3 months following inoculation. However, as in the landscape, palm trees died rapidly (within 1 to 2 months) once symptoms appeared. The remaining two replicate palm trees of each pathogen-inoculation treatment never exhibited symptoms during the 9-month incubation period. F. oxysporum was isolated from symptomatic petiole tissue, identified by sequencing the PCRamplified $E F-1 \alpha$ gene region, and confirmed to be the same as the original isolates used as inoculum at the start of the experiment.

Experiment 2. Based on the outcome of experiment $1, F$. oxysporum appeared to be pathogenic toward queen palm. However, because three Fusarium spp. were isolated from symptomatic palm trees, albeit $F$. proliferatum and FIESC less frequently than $F$. oxysporum, a second experiment was conducted to determine whether all three species were pathogens of queen palm. At 9 months post inoculation, all control palm trees remained healthy, as did palm trees inoculated with either $F$. proliferatum (PLM-137B) or with FIESC
(PLM-138B). By comparison, three of five palm trees inoculated with $F$. oxysporum PLM-140B by the pour-on method died after exhibiting typical foliar symptoms but only one of five palm trees inoculated by the injection method died. F. oxysporum was isolated from symptomatic petiole tissue. As in experiment 1 , no disease symptoms were observed on any inoculated palm for at least 3 months. However, when initial symptoms were observed, affected palm trees died within 1 to 2 months.

Experiment 3. Although experiments 1 and 2 implicated $F$. oxysporum as the sole pathogen of the new disease on queen palm, the inoculation techniques had required an extended post-inoculation period of 9 months before $50 \%$ mortality of the inoculated palm trees occurred. Therefore, we investigated whether a shorter time to complete the pathogenicity assay could be achieved. An experiment was conducted using palm seedlings in conjunction with a modification of the nonwounded pour-on inoculation method. By the time this experiment was initiated, the first diseased Mexican fan palm trees had been examined from which $F$. oxysporum was subsequently isolated; therefore, both queen and

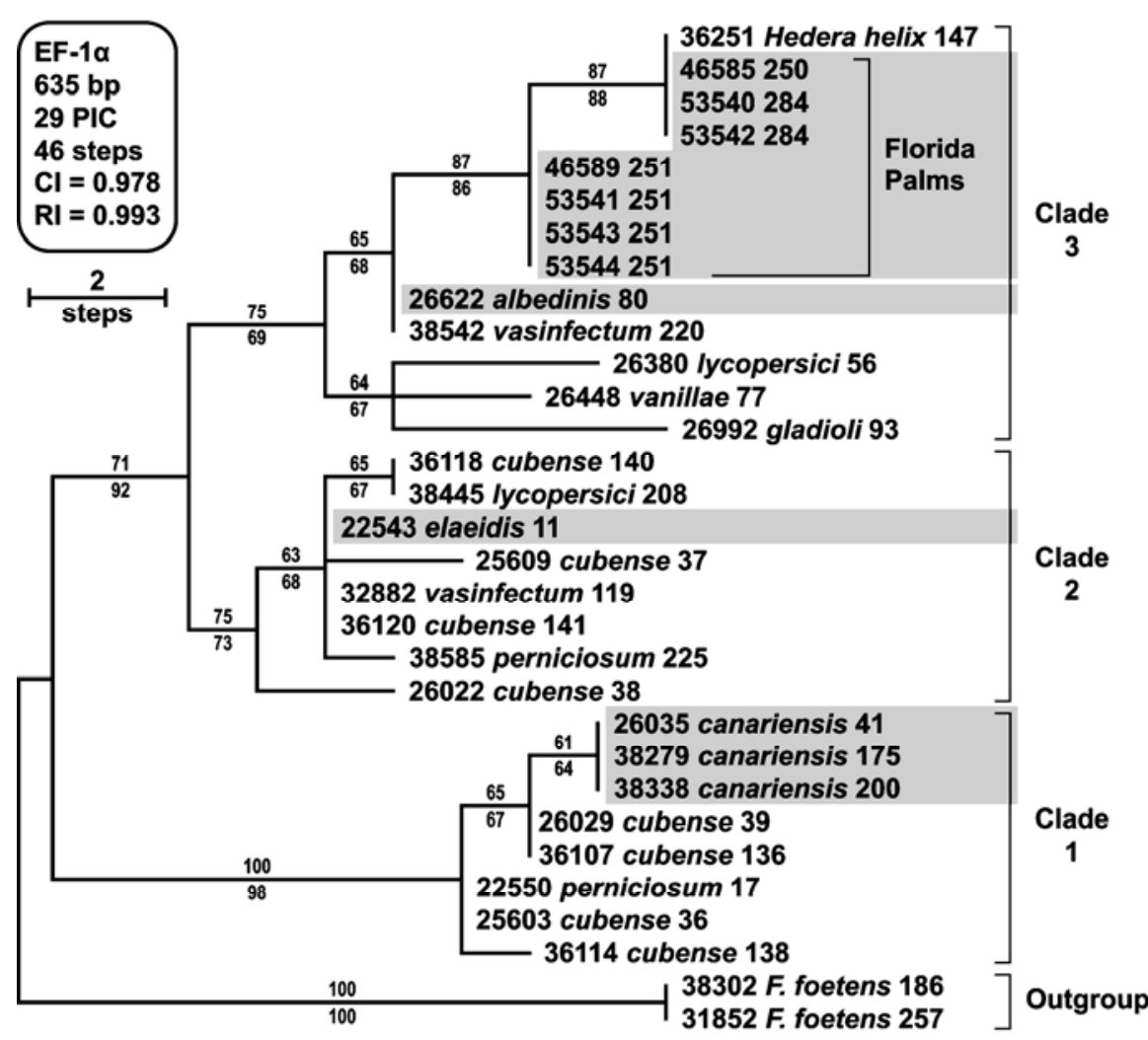

Fig. 3. Single most-parsimonious tree inferred from DNA sequence data from a portion of the translation elongation factor 1- $\alpha(E F-1 \alpha)$ gene from 29 members of the Fusarium oxysporum species complex (FOSC) rooted with two sequences of $F$. foetens, the sister group of the FOSC. Each isolate within the ingroup is identified by a five-digit NRRL number and forma specialis designation (except for the seven Florida palm strains and isolate NRRL 36251 from English ivy which are nested within clade 3), followed by the two-locus haplotype. Note that formae speciales pathogenic to palm trees are nested within all three clades. Maximum parsimony bootstrap support $>70 \%$, based on 1,000 pseudoreplicates of the data, is indicated above each node. PIC, parsimony informative character; CI, consistency index; RI, retention index. 
Mexican fan palm trees were used as hosts for inoculation with $F$. oxysporum isolates PLM-140B, PLM-246B, or PLM-249A. The first two isolates were from queen palm trees and the latter isolate was from Mexican fan palm. PLM-246B and PLM249A were from adjacent plots in a field nursery.

After the experiment was initiated in May 2007, symptoms were observed on Mexican fan palm trees 3 weeks post inoculation. All five replicate palm trees of all three $F$. oxysporum treatments were dead after 5 weeks. All control plants of Mexican fan palm trees remained healthy. Symptoms did not appear on queen palm trees until 8 weeks post inoculation, or 4 weeks sooner than was observed previously when juvenile queen palm trees were used for inoculations. By November 2007, all five replicate queen palm trees inoculated with PLM-249A had died. Similarly, three of five replicate queen palm trees inoculated with PLM-246B and two of five replicate queen palm trees inoculated with PLM-140B had died. By January 2008, none of the five surviving inoculated queen palm trees had died but all were severely stunted and had ceased to produce new leaves, and only the youngest leaf or leaves were still green. All control queen palm trees remained healthy and increased in size throughout the experiment. As before, $F$. oxysporum was isolated from symptomatic petiole tissue, identified by sequencing the PCR-amplified $E F-1 \alpha$ gene region, and confirmed to be the same as the original isolates used as inoculum at the start of the experiment.

In the repeat of this experiment, initiated in May 2008, similar results were observed for Mexican fan palm trees but queen palm trees expressed symptoms earlier than before. All five replicate Mexican fan palm trees subjected to the three $F$. oxysporum treatments were dead 6 weeks post inoculation. Symptoms on queen palm trees were first apparent 4 weeks post inoculation. By 12 weeks, four of five replicate palm trees in all three $F$. oxysporum treatments had died and all surviving palm trees were in decline, because only the youngest leaf and emerging spear leaf on each palm remained living. All control palm trees for both species remained symptomless.

Experiment 4. This experiment examined the pathogenicity of all three Fusarium spp. (F. oxysporum, $F$. proliferatum and FIESC) toward both queen and Mexican fan palm using seedlings as host palm trees and the pour-on inoculation method. Symptoms were first observed on Mexican fan palm trees 2 weeks after inoculation but only with the three $F$. oxysporum isolates (PLM-140B, PLM-246B, and PLM249A). Symptoms developed 3 weeks later on seedling queen palm trees inoculated with these same three isolates. By 12 weeks, all queen and Mexican fan palm trees inoculated separately with the three $F$. oxysporum isolates had died but all palm trees inoculated with either $F$. proliferatum (PLM-137B) or FIESC (PLM-138B) remained as healthy as the control palm trees. F. oxysporum was recovered from symptomatic tissue.

\section{DISCUSSION}

This new lethal disease of queen and Mexican fan palm trees is unique compared with all other currently know diseases of these palm species in Florida $(5,6)$. No other fungal disease kills the entire palm canopy so quickly, within a few months after observing initial symptoms. The appearance of the canopy shortly after all leaves have become necrotic is a very distinctive symptom, particularly on queen palm trees, because affected leaves remain in place and do not droop, break, and hang down around the trunk. Rather, the necrotic leaves remain rigid and upright.

Early leaf symptoms on Mexican fan palm trees could be confused with another disease referred to as rachis or petiole blight, because similar symptoms of onesided chlorosis and necrosis of the leaf blade with a corresponding reddish-brown stripe on the petiole are associated with this disease. Several fungi, including $\mathrm{Co}$ coicola californica (7), Diplodia spp., Phomopsis spp., and Macrophoma spp. (2), have been implicated as the probable causes of this disease on Mexican fan palm trees in Florida. Palm trees affected by petiole blight rarely succumb to the disease and, if they do, mortality is preceded by a protracted decline due to a gradual weakening of the palm as each leaf slowly dies (M. L. Elliott, unpublished).

Early on in the investigation of this new disease on queen palm trees, the fact that $F$. oxysporum was consistently isolated from diseased palm trees was not surprising based on the early leaf symptoms observed, which are similar to Fusarium wilt of Canary Island date palm. What was unexpected, however, was the discovery that the etiological agent is a new forma specialis of $F$. oxysporum, for which we propose the designation $\mathrm{f}$. sp. palmarum. Because we occasionally isolated $F$. proliferatum or FIESC, or both, from diseased palm trees, it was important to determine whether either of these species were capable of causing disease on queen and Mexican fan palm trees, especially because $F$. proliferatum has been documented as a pathogen of ornamental palm trees in Italy (18), Saudi Arabia (1), and Spain (4), and F. semitectum (an FIESC member) is often isolated from Canary Island date palm with Fusarium wilt symptoms in Australia (20). It was evident from our study that neither $F$. proliferatum nor the FIESC isolate was the cause of the queen or Mexican fan palm disease; only $F$. oxysporum f. sp. palmarum was pathogenic to these hosts.
Characteristically, $F$. oxysporum f. sp. palmarum kills queen and Mexican fan palm trees more quickly in the landscape than $F$. oxysporum f. sp. canariensis kills Canary Island date palm trees, a disease that is also present in Florida (19). It may take a year or more before the latter palm species dies after the onset of Fusarium wilt symptoms, whereas queen and Mexican fan palm trees die within just a few months. In repeated attempts to demonstrate pathogenicity of $F$. oxysporum f. sp. canariensis toward Canary Island date palm seedlings by employing the same inoculation technique used for queen and Mexican fan palm seedlings (pour-on method), no seedlings were observed to develop foliar symptoms of disease even after 9 months (M. L. Elliott, unpublished).

The quick decline and death of both queen and Mexican fan palm trees induced by $F$. oxysporum f. sp. palmarum is reminiscent of "acute wilt" of Elaeis guineensis (African oil palm) caused by $F$. oxysporum f. sp. elaeidis (10). P. dactylifera (date palm) may also die rapidly after the onset of Bayoud disease symptoms, caused by $F$. oxysporum f. sp. albedinis $(8,24)$. Fungal toxins have been implicated in the pathogenicity and virulence of this latter pathogen (3).

It is somewhat surprising that this new forma specialis of $F$. oxysporum has multiple hosts. Although both hosts are members of the family Arecaceae, they belong to different tribes-genus Syagrus is in the tribe Cocoeae and genus Washingtonia is in the tribe Corypheae. Similarly, F. oxysporum f. sp. canariensis reportedly has multiple hosts, too. Canary Island date palm appears to serve as the primary host but this forma specialis is also associated with diseased $W$. filifera (California or desert fan palm) in California and Australia (20). By way of contrast, $F$. oxysporum f. sp. albedinis is only known to be a pathogen on date palm and African oil palm is the only known host of $F$. oxysporum $\mathrm{f}$. sp. elaeidis.

Partial $E F-1 \alpha$ gene sequence analysis separated the $F$. oxysporum f. sp. palmarum isolates into two groups (Fig. 2). Isolates from both groups-PLM-140B represents the smaller group while PLM-246B and PLM-249A are members of the larger group-were tested for pathogenicity on both queen and Mexican fan palm trees, and all three isolates were pathogenic on both palm species. Based on combined partial $E F-1 \alpha$ sequences and nearly complete IGS rDNA sequences, three twolocus haplotypes (sequence types) were identified among $10 \mathrm{~F}$. oxysporum $\mathrm{f}$. sp. palmarum isolates subjected to this typing scheme. STs 250 (represented by PLM140B/NRRL 46585) and 251 (represented by PLM-246B/NRRL 53541 and PLM249A/NRRL 53543) were isolated from both queen and Mexican fan palm trees and on both coasts of Florida, and both 
types were pathogenic on both palm species. The third ST identified, ST 284, is represented by two isolates (PLM-320B/ NRRL 53542 and PLM-321E/NRRL 53540) from a single Syagrus $\times$ Butia hybrid palm. Pathogenicity of these latter two isolates has not been confirmed; however, STs 250 and 284 belong to the same $E F-1 \alpha$ group. Likewise, although $\mathrm{f}$. sp. palmarum STs 250 and 284 share an identical $E F-1 \alpha$ allele with a putative pathogen of English ivy from England (NRRL 36251 ex Hedera helix $=$ ST 147) (Fig. 3), pathogenicity assays will need to be conducted to determine the relationship between ST group, $E F-1 \alpha$ group, and pathogenicity.

MP analysis of the partial $E F-1 \alpha$ gene from representative isolates of $F$. $o x$ ysporum f. sp. palmarum, f. sp. albedenis, f. sp. canariensis, and f. sp. elaeidis and 19 members of the FOSC placed f. sp. palmarum and f. sp. albedenis into clade 3 , f. sp. canariensis into clade 1 , and f. sp. elaeidis into clade 2 (Fig. 3). This suggests that $f$. sp. palmarum and f. sp. albedenis may be more closely related to one another than either is to f. sp. canariensis or f. sp. elaeidis. F. oxysporum f. sp. albedenis has previously been reported as a pathogen with a single clonal lineage (22). In contrast, F. oxysporum f. spp. canariensis and elaeidis have been shown to be genetically diverse $(10,12,17)$.

In the present study, most samples were obtained from established landscapes; palm trees had been in their current location for 5 to 20 years. The sample sites ranged from the west to east coasts of Florida, encompassing the southern half of the state. The widespread occurrence of this disease suggests that the pathogen may have been present for a number of years prior to its initial discovery, or that it has been rapidly spread by airborne conidia moved by wind, birds, or insects. Thus far, only juvenile palm trees in one container nursery and two field nurseries have been affected by the disease. Because the palm trees declined so quickly, they were not marketable. If this is the normal scenario, although devastating to the nursery, it is unlikely that symptomatic palm trees will be moved into landscapes. However, whether infected but asymptomatic palm trees are being moved is unknown at this time. It should be noted that the field nursery site in Lee County is on a relatively isolated barrier island, and no mature queen or Mexican fan palm trees were known to have died in the vicinity and none were observed when the samples were obtained. Soil infestation was not evident in this field. As in the landscape, roots of palm trees in the field nursery were healthy and there were no discolored vascular bundles leading into the symptomatic petioles. It is unknown how the disease was initially established in the nursery but subsequent dissemina- tion of the pathogen could have been by pruning tools, because pruning had obviously occurred.

A number of queen palm samples were obtained from the city of Lakewood Ranch (Manatee County) and initially were centered in one subdivision (WM) (Table 1). Later, positive samples were obtained from two more subdivisions (SG and EW), separated by a very large lake. Further investigation determined that each subdivision was serviced by different landscape maintenance companies. This would indicate that it is highly unlikely that infested pruning tools were the primary means of pathogen transmission among subdivisions. It was also deemed highly unlikely that pruning transmission of the pathogen occurred at the Orlando development in Orange County. All three sites are at least $1 \mathrm{~km}$ from each other and were either not trimmed by the same crew or were trimmed months apart. This is in contrast to Fusarium wilt of Canary Island date palm, where pruning transmission is considered to be a primary means of transmission of $F$. oxysporum f. sp. canariensis $(12,19)$.

Pathogen movement by means other than pruning tools (e.g., wind, birds, and insects) would imply that conidia of this pathogen are being produced externally, and this has been observed in the landscape. As palm petioles and rachides age or degrade, superficial cracks develop that may allow the fungus to sporulate on the exterior of these tissues. This also has implications for replanting susceptible host species back into a site where $F$. oxysporum f. sp. palmarum has killed palm trees.

Further research is needed to determine whether (i) other palm species are susceptible to this pathogen, (ii) toxins are involved in pathogenicity and virulence, (iii) fungal spores are incorporated into the soil leading to root infections of replacement plantings, and (iv) fungicides could be used to protect susceptible palm trees in areas where the disease is active.

\section{ACKNOWLEDGMENTS}

This research was supported, in part, by the Florida Nursery Growers and Landscape Association. We thank S. Sink for expert technical assistance and D. Fraser for preparing Figure 3.

\section{LITERATURE CITED}

1. Abdalla, M. Y., Al-Rokibah, A., Moretti, A., and Mulè, G. 2000. Pathogenicity of toxigenic Fusarium proliferatum from date palm in Saudi Arabia. Plant Dis. 84:321-324.

2. Alfieri, S. A., Jr., Langdon, K. R., Kimbrough, J. W., El-Gholl, N. E., and Wehlburg, C. 1994. Diseases and Disorders of Plants in Florida. Florida Dep. Agric. Consumer Serv. Div. Plant Ind. Bull. 14

3. Amraoui, H., Lazrek, H. B., Sedra, M. H., Sampieri, F., Mansuelle, P., Rochat, H., and Hamdaoui, A. 2005. Chromatographic characterization and phytotoxic activity of Fusarium oxysporum f. sp. albedinis and saprophytic strain toxins. J. Phytopathol. 153:203-208.

4. Armengol, J. Moretti, A., Perrone, G., Vicent,
A., Bengoechea, J. A., and Garcia-Jiménez, J. 2005. Identification, incidence and characterization of Fusarium proliferatum on ornamental palms in Spain. Eur. J. Plant Pathol. 112:123131.

5. Downer, A. J., Uchida, J. Y., Hodel, D. R., and Elliott, M. L. 2009. Lethal palm diseases in the United States. HortTechnology 19:710-716.

6. Elliott, M. L., Broschat, T. K., Uchida, J. Y., and Simone, G. W., eds. 2004. Compendium of Ornamental Palm Diseases and Disorders. The American Phytopathological Society, St. Paul, MN.

7. Elliott, M. L., and Des Jardin, E. A.. 2006. First report of Cocoicola californica on Washingtonia robusta in Florida. Online. Plant Health Progr. doi:10.1094/PHP-2006-0227-01BR.

8. Elmer, H. S., Carpenter, J. B., and Klotz, L. J. 1968. Pests and diseases of the date palm. Part II. Diseases. FAO Plant Prot. Bull. 16:97-110.

9. Feather, T. V., Ohr, H. D., Munnecke, D. E., and Carpenter, J. B. 1989. The occurrence of Fusarium oxysporum on Phoenix canariensis, a potential danger to date production in California. Plant Dis. 73:78-80.

10. Flood, J. 2006. A review of Fusarium wilt of oil palm caused by Fusarium oxysporum f. sp. elaeidis. Phytopathology 96:660-662.

11. Geiser, D. M., Jimenez-Gasco, M. M., Kang, S., Makalowska, I., Veeraraghavan, N., Ward, T. J., Zhang, N., Kuldau, G. A., and O'Donnell, K. 2004. FUSARIUM-ID v. 1.0: A DNA sequence database for identifying Fusarium. Eur. J. Plant Pathol. 110:473-479.

12. Gunn, L. V., and Summerell, B. A. 2002. Differentiation of Fusarium oxysporum isolates from Phoenix canariensis (Canary Island Date Palm) by vegetative compatibility grouping and molecular analysis. Aust. Plant Pathol. 31:351-358.

13. Harrison, N. A., and Jones, P.. 2004. Lethal yellowing. Pages 39-41 in: Compendium of Ornamental Palm Diseases and Disorders. M. L. Elliott, T. K. Broschat, J. Y. Uchida, and G. W. Simone, eds. The American Phytopathological Society, St. Paul, MN.

14. Kumar, S., Tamura, K., and Nei, M. 2004 MEGA3: Integrated software for molecular evolutionary genetics analysis and sequence alignment. Brief. Bioinf. 5:150-163.

15. Leslie, J. F., and Summerell, B. A.. 2006. The Fusarium Laboratory Manual. Blackwell Publishing, Ames, IA.

16. O’Donnell, K., Gueidan, C., Sink, S., Johnston, P. R., Crous, P. W., Glenn, A., Riley, R., Zitomer, N., Coyler, P., Waalwijk, C., van der Lee, T., Moretti, A., Kang, S., Kim, H.-S., Geiser, D. M., Juba, J., Baayen, R. P., Cromey, M. G., Bithel, S., Sutton, D. A., Skovgaard, K., Ploetz, R., Kistler, H. C., Elliott, M., Davis, M., and Sarver, B. A. J. A two-locus DNA sequence database for typing plant and human pathogens within the Fusarium oxysporum species complex. Online. Fungal Genet. Biol. (2009) doi:10.1016/j.fgb.2009.08.006

17. Plyler, T. R., Simone, G. W., Fernandez, D., and Kistler, H. C. 2000. Genetic diversity among isolates of Fusarium oxysporum $\mathrm{f}$. sp. canariensis. Plant Pathol. 49:155-164.

18. Polizzi, G., and Vitale, A. 2003. First report of Fusarium blight on majesty palm caused by Fusarium proliferatum in Italy. Plant Dis. 87:1149.

19. Simone, G. W. 2004. Fusarium wilt. Pages 17 22 in: Compendium of Ornamental Palm Diseases and Disorders. M. L. Elliott, T. K. Broschat, J. Y. Uchida, and G. W. Simone, eds The American Phytopathological Society, St. Paul, MN.

20. Summerell, B. A., Kistler, H. C., and Gunn, L. V. 2001. Fusarium wilt of Phoenix canariensis caused by Fusarium oxysporum f. sp. canariensis. Pages 263-270 in: Fusarium: Paul E. 
Nelson Memorial Symposium. B. A. Summerell, J. F. Leslie, D. Backhouse, W. L. Bryden, and L. W. Burgess, eds. The American Phytopathological Society, St. Paul, MN.

21. Swofford, D. L. 2002. PAUP*. Phylogenetic analysis using parsimony (*and other methods), version 4. Sinauer Associates, Sunderland, MA.
22. Tantaoui, A., Ouinten, M., Geiger, J.-P., and Fernandez, D. 1996. Characterization of a single clonal lineage of Fusarium oxysporum $\mathrm{f}$. sp. albedinis causing Bayoud disease of date palm in Morocco. Phytopathology 86:787-792.

23. Thompson, J. D., Higgins, D. G., and Gibson, T. J. 1994. CLUSTAL W: improving the sensitivity of progressive multiple sequence align- ment through sequence weighting, positionspecific gap penalties and weight matrix choice. Nucleic Acids Res. 22:4673-4680.

24. Zaid, A., de Wet, P. F., Djerbi, M., and Oihabi, A. 1999. Diseases and pests of date palm. Pages 223-287 in: Date Palm Cultivation. Zaid,

A., ed. FAO Plant Production and Protection Paper 156. 